\title{
ANALISIS KEBUTUHAN BUKU AJAR \\ PERCAKAPAN BAHASA JEPANG YANG \\ BERORIENTASI HOSPITALITY BAGI \\ MAHASISWA PROGRAM INTERNSHIP D3 \\ BAHASA JEPANG UTY
}

\author{
TETI INDRIATI KASTUTI \\ Program Studi D3 Bahasa Jepang \\ Universitas Teknologi Yogyakarta \\ tetiindriati@uty.ac.id
}

\begin{abstract}
ABSTRAK
Hospitality merupakan salah satu pokok bahasan dalam mata kuliah gaido. Tujuan penelitian ini adalah untuk menganalisis kebutuhan pengembangan buku ajar mata kuliah gaido yang berorientasi pada hospitality bagi mahasiswa D3 Bahasa Jepang Universitas Teknologi Yogyakarta khususnya mahasiswa calon program internship di hotel yang ada di Jepang, yang selanjutnya dijadikan pijakan untuk pengembangan buku ajar. Penelitian ini merupakan penelitian deskriptif kualitatif. Tahapan analisis merujuk pada tahap analis dalam model pengembangan ADDIE. Teknik pengumpulan data dilakukan dengan penyebaran angket, observasi, dan wawancara. Dari hasil wawancara dengan mahasiswa yang sedang mengikuti program internship ditemukan bahwa :(1) keterampilan berbicara mahasiswa program internship masih kurang disebabkan materi bahan ajar belum bisa memfasilitasi kebutuhan mahasiswa program internship (2) salah satu upaya untuk meningkatkan keterampilan berbicara bagi mahasiswa yang mengikuti program internship adalah menyediakan buku ajar percakapan yang berorientasi pada hospitality (3) untuk pengembangan buku ajar percakapan yang berorientasi pada hospitality perlu sumber literatur yang terkini agar mahasiswa dapat mengimplementasikan secara langsung dengan setting situasi yang nyata.

Kata Kunci: hospitality, buku ajar, keterampilan berbicara, ADDIE
\end{abstract}




\section{ABSTRACT}

Hospitality is one of materials in gaido course. The research objective is to analyse the need of developing gaido instructional material which oriented to hospitality for students of D3 Japanese at Univeristy of Technology Yogyakarta especially students who will take internship program as the basis of instructional material development in the future. This research belongs to descriptive qualitative research. Analysis stage refers to analyze step in ADDIE development model. Data collecting technnique is conducted through questionnaire distribution, observation, and interview. From the interview with students who are taking intership program, it finds that: (1) speaking skill of students who taking internship program is till low since the course material has not facilitate the need of of those students (2) one of the efforts to improve speaking skill of students who taking internship program is by providing conversation instructional material which oriented to hospitality (3)to develop conversation instructional materialwhich is oriented to hospitality needs the latest literature source so students are able to implement in real situation setting directly.

Keyword:hospitality, instructional material, ADDIE

\section{Pendahuluan}

Pendidikan tinggi vokasi mengambil peran dalam menghasilkan lulusan kompeten dengan kualifikasi yang cocok dengan tantangan yang dihadapi bangsa Indonesia. Pendidikan tinggi vokasi mampu secara tepat mengidentifikasi kebutuhan di lingkungannya dan menyiapkan proses pembelajaran yang menjamin lulusannya dapat menjawab tantangan tersebut. Lulusan pendidikan tinggi vokasi selain dituntut dapat bekerja dengan kompeten namun harus juga dapat berperan sebagai "agen pejuang kedaulatan" yang memiliki kemampuan entrepreneurial. Pada jenjang pendidikan tinggi vokasi lulusannya juga harus menjadi "trend setter" dalam menjawab berbagai aspek tantangan bangsa. Pendidikan vokasi merupakan pendidikan tinggi program diploma yang menyiapkan mahasiswa untuk pekerjaan dengan keahlian terapan tertentu. Berdasarkan Peraturan Presiden RI No. 8 Tahun 2012 tentang Kerangka Kualifikasi 
Nasional Indonesia pendidikan tinggi vokasi khususnya Diploma III harus berkembang dari institusi yang berperan pada penyiapan lulusan pada level 5 Kerangka Kualifikasi Nasional Indonesia (KKNI). Hal ini bukan hanya akan mengubah perangkat operasionalnya, namun secara mendasar juga akan mengubah Visi dan Misi secara keseluruhan. Perluasan mandat tersebut berimplikasi pada beberapa aspek, diantaranya: penyesuaian program pendidikan (program studi), sistem kurikulum, pola dan metode pembelajaran, riset yang diselenggarakan, peran dalam masyarakat, sumber daya manusia, sarana dan prasarana. Beberapa aspek dimaksud harus dipersiapkan dengan baik dan menyeluruh oleh penyelenggara pendidikan tinggi vokasi. Pendidikan vokasi memiliki ciri atau kekhasan dan mengutamakan dalam menerapkan aspek-aspek praktis yang didukung oleh teori yang tepat. Hal ini untuk membedakan terhadap pendidikan akademis yang lebih mengutamakan capaian teoretis didukung aspek praktis. Ketepatan komposisi antara praktik dan teori pendukung menjadi kunci keberhasilan penyelenggaraan proses pendidikan pada pendidikan tinggi vokasi. Komposisi praktik lebih dominan daripada teori menjad ciri khas pendidikan vokasi. Panduan Penyusunan Kurikulum Pendidikan Vokasi menjelaskan bahwa kurikulum dan pembelajaran menggunakan dual sistem 3-2-1 untuk jenjang pendidikan D3 masih relevan dan sesuai dalam penerapannya. Mahasiswa di awal belajar/ kuliah diberi kesempatan untuk menempuh pendidikan di kampus selama tiga (3) semester dilanjutkan dengan dua (2) semester magang di industri, dan diakhiri satu (1) semester untuk menyelesaiakan pendidikan dikampus atau di industri. Dalam penyelenggaraan ini pola pendidikan 3-2-1 institusi pendidikan tinggi penyelenggara program vokasi bekerjasama dengan industri yang relevan. Selama magang di industri, mahasiswa yang memiliki kompetensi dapat memperoleh surat keterangan atau sertifikasi kompetensi.

Program Studi D3 Bahasa Jepang Fakultas Humaniora Universitas Teknologi Yogyakarta memberikan pendidikan vokasional dalam bidang bahasa Jepang untuk mencetak Ahli Madya Bahasa Jepang yang berkepribadian unggul, terampil, memiliki disiplin tinggi dan berdaya saing tinggi dengan keahlian praktikal untuk terjun langsung ke industri bisnis 
yang membutuhkan keterampilan berbahasa Jepang. Untuk mendukung hal tersebut Program Studi Bahasa Jepang Universitas Teknologi Yogyakarta menerapkan kurikulum berbasis KKNI yang mengintegrasikan keterampilan praktikal berbahasa Jepang dan keterampilan di bidang hospitality industry dan entrepreneurship dengan total 110 SKS untuk mencetak mahasiswa yang memiliki keterampilan praktikal berbahasa Jepang. Yang menjadi kekhasan prodi dalam menunjang industri hosptality adalah pendalaman bahasa Jepang dalam mata kuliah bijinisu nihongo (bahasa Jepang untuk bisnis) dan gaido (bahasa Jepang untuk guiding).

Dalam menerapkan kurikulum dan pembelajaran dual sistem, D3 Bahasa Jepang UTY telah bekerja sama dengan JIPA (Japan Indonesia Program Akademik) dan IFECE (International Foundation of Educational and Cultural Exchange) dengan memberangkatkan mahasiswa pada program internship selama satu tahun di hotel yang berada di Jepang. Dalam Peraturan Menteri Riset Teknologi dan Pendidikan Tinggi No.44 Tahun 2015 pasal 9 disebutkan bahwa lulusan program diploma 3 paling sedikit menguasai konsep teoretis bidang pengetahuan dan keterampilan tertentu secara umum. Dengan mengikuti program ini diharapkan kemampuan bahasa Jepang mahasiswa meningkat sesuai dengan tuntutan di lapangan kerja bidang perhotelan baik dalam negeri maupun luar negeri. Namun pada kenyataannya selama proses magang banyak kendala yang dihadapi. Selain itu dari hasil wawancara dengan dosen pengampu bahwa keterampilan berbicara mahasiswa selama kuliah di lapangan masih rendah. Keterampilan berbicara berkaitan erat dengan tindakan, seperti yang dikatakan oleh Tarigan (1997) yaitu berbicara adalah sebagai sesuatu yang berhubungan dengan tindakan menyatakan sesuatu kepada seseorang dalam bentuk ujaran (bahasa lisan).

Adapun penyebab munculnya kendala tersebut ada beberapa faktor diantaranya masih terbatasnya bahan ajar berupa kosakata yang berhubungan dengan perhotelan dan percakapan saat melayani tamu. Sugiarto (2011) menyatakan buku ajar adalah buku yang disusun untuk kepentingan proses pembelajaran baik yang bersumber dari hasil-hasil penelitian atau hasil dari 
sebuah pemikiran tentang sesuatu atau kajian bidang tertentu yang kemudian dirumuskan menjadi bahan pembelajaran. Komalasari (2010) menyatakan buku teks merupakan buku pelajaran dalam bidang studi tertentu yang merupakan buku standar, yang disusun oleh para pakar dalam bidang itu dengan maksud dan tujuan instruksional, dilengkapi dengan sarana-sarana pembelajaran yang serasi dan mudah dipahami oleh para pemakainya di sekolah-sekolah dan pergururan tinggi sehingga dapat menunjang suatu program pembelajaran.

Dick dan Carey (2009: 230) mengemukakan, "instructional material contain the content either written, mediated, or facilitated by an instructor that a student as use to achieve the objective also includes information that the learners will use to guide the progress", yang artinya bahan ajar berisi konten yang berbentuk cetak, dimediasi, atau yang difasilitasi oleh pengajar yang digunakan siswa untuk mencapai tujuan juga termasuk informasi yang akan digunakan siswa untuk memandu kemajuan. Bahan ajar adalah seperangkat sarana atau alat pembelajaran yang berisikan materi pembelajaran, metode, batasan-batasan, dan cara mengevaluasi yang didesain secara sistematis dan menarik dalam rangka mencapai tujuan yang diharapkan, yaitu mencapai kompetensi atau subkompetensi dengan segala kompleksitasnya (Widodo dan Jasmadi dalam Lestari, 2013:1). Pengertian ini menggambarkan bahwa bahan ajar hendaknya dirancang dan ditulis sesuai dengan kaidah pembelajaran, yakni disesuaikan materi pembelajaran, disusun berdasarkan atas kebutuhan pembelajaran, terdapat bahan evaluasi, serta bahan ajar tersebut menarik untuk dipelajari oleh siswa.

Bahan ajar dapat dikelompokkan menjadi empat, yaitu: (1) Bahan cetak (printed) antara lain handout, buku, modul, lembar kerja siswa, brosur, surat kabar atau selebaran (leaflet), wallchat, foto gambar, model/maket. (2) Bahan ajar dengan audio seperti seperti kaset, radio, piringan hitam, dan audio compact disk. (3) Bahan ajar dengan padangan dengar (audio visual) seperti video compact disk dan film. (4) Bahan ajar interaktif (interactive teaching material) seperti compact disk interaktif (Abdul Majid, 2011: 274). Sedangkan secara abstrak bahan ajar berisi materi pembelajaran 
(instructional materials) yang secara garis besar terdiri dari pengetahuan, keterampilan, dan sikap yang harus dipelajari siswa dalam rangka mencapai standar kompetensi yang telah ditentukan. Secara terperinci jenis-jenis materi pembelajaran terdiri dari pengetahuan (fakta, konsep, prinsip, prosedur), keterampilan dan sikap atau nilai (Ali Mudlofir, 2012: 128).

D3 Bahasa Jepang UTY memberikan mata kuliah gaido. Mata kuliah gaido menggunakan buku yang disusun oleh dosen tetap UTY yang sudah berpengalaman dalam guiding, namun buku khusus yang digunakan dalam dunia hospitality belum tersedia. Selain itu percakapan dalam mata kuliah gaido hanya seputar tempat wisata yang ada di Yogyakarta.

Penelitian mengenai pembelajaran untuk pariwisata sudah dikaji sebelumnya oleh Anisa Arianingsih dan Soni Mulyawan Setiana yang berjudul evaluasi pembelajaran Japanese for Toursm yang mencakup bahan ajar dan metode pengajaran. Hasil evaluasi menunjukkan bahwa pembelajaran Japanese for Tourism ini dapat dikatakan baik. Hal tersebut terlihat dari perolehan nilai yang dicapai mahasiswa yaitu $66,67 \%$ mendapatkan nilai sangat baik dan 33,33\% mendapatkan nilai baik. Dari hasil kuesioner dan wawancara yang diberikan pada mahasiswa dapat diketahui bahwa bahan ajar dan metode pengajaran sudah baik.

Berdasarkan hasil evaluasi dapat disimpulkan bahwa penelitian evaluasi pembalajaran hanya meneliti dari perolehan nilai di kelas dengan sebuah modul yang diambil dari buku Japanese for toursm dan internet, sehingga buku ajar yang difokuskan untuk melayani tamu belum tersedia, sedangkan yang diperlukan adalah buku yang bisa menyentuh kompetensi bidang perhotelan khususnya hospitality untuk mengembangkan potensi diri mahasiswa yang siap dalam melayani tamu sehingga dapat bersaing dengan dunia luar dalam menghadapi era global. Buku ajar yang tersedia belum menampung materi yang relevan dengan kebutuhan mahasiswa yang ikut serta program internship. Selain dari buku ajar yang kurang menunjang terhadap keterampilan berbicara mahasiswa, materi tersebut tidak menyinggung percakapan tata cara atau perilaku seseorang saat melayani tamu di hotel.

Salah satu upaya yang dapat dilakukan untuk meningkatkan 
keterampilan berbicara mahasiswa program internship adalah dengan menyediakan buku ajar percakapan yang berorientasi pada hospitality. Hospitality adalah terjemahan dari kata benda Latin hospitium (atau kata sifatnya hospitalis), yang berasal dari hospes, yang artinya 'tamu' atau 'tuan rumah'. Konsep ini juga dipengaruhi oleh kata Yunani xenos, yang menunjuk kepada orang asing yang menerima sambutan atau yang melakukan penyambutan terhadap orang lain.

Menurut A. Bambang Sujatno (2011) ada beberapa pengertian hospitality berdasarkan beberapa sumber, yaitu the reception and entertainment of guests, visitors or strangers with liberality and goodwill (The Oxford English Dictionary), keramah-tamahan, kesukaan/kesediaan menerima tamu (Kamus Inggris-Indonesia, John M.Echols dan Hassan Shadily), hospitable=offering a friendly welcome to guests. Hospitality=being hospitable (Longman Handy Learners: Dictionary). Hospitality pada umumnya menunjukkan hubungan antara tamu dengan tuan rumah yang penuh dengan keramah-tamahan, sikap atau perilaku yang penuh dengan keramahan dalam memberikan pelayanan maupun perhatian dan kebaikan kepada siapa pun yang memerlukan (A. Bambang Sujatno, 2011:3).

Hershberger (1999) hospitality memiliki arti keramahtamahan, kesopanan, keakraban, dan rasa saling menghormati. Jika dikaitkan dengan industri pariwisata, dapat diibaratkan bahwa hospitality merupakan roh, jiwa, semangat dari pariwisata. Tanpa adanya hospitality dalam pariwisata, maka seluruh produk yang ditawarkan dalam pariwisata itu sendiri seperti benda mati yang tidak memiliki nilai untuk dijual (S. Pendit, 2007 : 152). Hospitality didefinisikan sebagai kata friendly yang artinya 'ramah' yang 'murah hati' atau 'dermawan' dan memberikan hiburan kepada tamu atau orang baru. Kadangkadang sering digunakan untuk memberikan perlakuan istimewa terhadap tamu yang tinggal dan menggunakan fasilitas keramah-tamahan. Adapun industri hospitality dapat diartikan sebagai perusahaan yang terlibat dalam penyediaan jasa untuk tamu (Conciere Oxford Dictionary).

Kata melayani tamu dalam bahasa Jepang adalah omotenashi berasal dari motenashi yang mempunyai arti bagaimana cara memperlakukan/ 
melayani tamu (現代国語辞典). Arakawa (2016) omotenashi merupakan gabungan makna memegang 'motte' dan menyelesaikan 'nasu'. Istilah omotenashi dimaknai sebagai perilaku yang berasal dari setiap diri individu yang diekspresikan dalam memberi pelayanan, pengaturan, management dan perawatan berbagai macam alat yang digunakan. Nakano (2008) omotenashi mengalami transisi dari auto-mobiles hingga maskapai penerbangan, restoran hingga rumah pensiunan, industri manufaktur dan jasa, semua aspek memiliki dan memberikan unsur omotenashi .

Sen Genshitsu dan Sen Shoshitsu (2014) konsep utama omotenashi lahir dari ichigo ichie (一期一会) yang berarti menghargai tiap momen dengan penekanan kepada hubungan orang-orang yang berkumpul dianggap sebagai sebuah kejadian yang terjadi sekali seumur hidup. Makna ichigo ichie menjelaskan secara detil hal-hal yang perlu diperhatikan dari awal sampai akhir oleh penjamu dan tamu saat chanoyu 'jamuan teh'. Inilah yang menjadi alasannya dinamai koleksi pertemuan dalam chanoyu. Kata ichie dan pertemuan memiliki makna penting. Pertama, hubungan orang yang berkumpul untuk chanoyu adalah pertemuan sekali seumur hidup yang disebut sebagai ichigo ichie. Baik penjamu dan tamu menyadari hal tersebut berapa kali pun mereka melaksanakan chanoyu, hari yang sama tidak akan terulang. Oleh karena itu, jika tiap pertemuan dikatakan hanya terjadi sekali seumur hidup, hal itu ada benarnya. Karena sebab ini pula, tuan rumah biasanya akan sangat memperhatikan dan berusaha untuk menjamu tamu sebaik mungkin. Sebagai gantinya, para tamu akan menghargai tiap bentuk perhatian yang diberikan tuan rumah. Inilah makna ichigo ichie. Pesan terdalam yang ada dalam naskah ini ichie shu adalah baik penjamu dan tamu tidak boleh mengikuti perjamuan teh tanpa persiapan.

Penelitian ini bertujuan untuk menganalisis kebutuhan pengembangan buku ajar mata kuliah gaido berorientasi hospitality bagi mahasiswa program internship D3 Bahasa Jepang UTY. Tahapan dalam analisis kebutuhan merujuk pada model pengembangan ADDIE (Analyze Design Develop ImplementEvaluation), yaitu tahap analyze Branch (2009) analisis kebutuhan ini selanjutnya dijadikan sebagai pijakan dalam mengembangkan buku ajar 
untuk mata kuliah gaido. Pemilihan model pengembangan ini didasarkan pada konsep ADDIE namun memberikan banyak petunjuk dalam proses pengembangan suatu produk pembelajaran. Selain itu, model pengembangan ADDIE berbentuk siklus sehingga cukup fleksibel bagi siapa pun dan kapan pun dalam mengulangi langkah dan memperbaikinya.

\section{Metode Penelitian}

Penelitian dilakukan pada bulan Juli 2017, diawali dengan wawancara terhadap 10 mahasiswa program internship D3 Bahasa Jepang UTY yang sedang melakukan magang di beberapa hotel yang ada di Jepang.

Tabel 1. Mahasiswa Program Internship 2016-2017

\begin{tabular}{|l|l|l|}
\hline No. & \multicolumn{1}{|c|}{ Nama } & \multicolumn{1}{c|}{ Hotel } \\
\hline 1 & $\begin{array}{l}\text { Rachmaretta Wira } \\
\text { Nararyani }\end{array}$ & Peche Mignon, Hakodate \\
\hline 2 & Wahyuningsih & Snaffles, Sapporo \\
\hline 3 & Fanny Febriana & Coganoi Resort \& Spa, Shirahama \\
\hline 4 & Dycha Amalia & Coganoi Resort \& Spa, Shirahama \\
\hline 5 & Puspa Indrati & Fusui Hotel,Shikaoi, Hokkaidou \\
\hline 6 & Nufi Kuswindarti & Jouzankei onsen, Saporo \\
\hline 7 & & $\begin{array}{l}\text { Onishiya,Suishoen, Kinosaki, Mo- } \\
\text { moshima }\end{array}$ \\
\hline 8 & $\begin{array}{l}\text { Endah Putri } \\
\text { Handayani }\end{array}$ & $\begin{array}{l}\text { Onishiya,Suishoen, Kinosaki, Mo- } \\
\text { moshima }\end{array}$ \\
\hline 9 & & $\begin{array}{l}\text { Sounkyo hotel, Kamikawa. Hok- } \\
\text { kaido }\end{array}$ \\
\hline 10 & Jdilla Metasari & $\begin{array}{l}\text { Sounkyo hotel, Kamikawa. Hok- } \\
\text { kaido }\end{array}$ \\
\hline
\end{tabular}

Penelitian ini merupakan penelitian deskriptif kualitatif. Tahapan analisis kebutuhan merujuk pada tahap analyze dalam model pengembangan 
ADDIE (Branch, 2009), yaitu:

a. memvalidasi ketidakseimbangan kondisi nyata dengan kondisi ideal (validate the performance gap);

b. menentukan tujuan pembelajaran (determineinstructionalgoals);

c. melakukan konfirmasi kepada target sasaran produk (confirmthe intendedaudience);

d. mengidentifikasi hal-hal yang dibutuhkan dalam pengembangan (identifyrequiredresources);

e. menentukan sistem pengantar yang potensial (determinepotentialdeliverysystem)

Teknik pengumpulan data dilakukan dengan wawancara, observasi, dan penyebaran angket.

\section{Hasil dan Pembahasan}

3.1 Memvalidasi kesenjangan antara kondisi nyata dengan kondisi ideal (validate the performance gap)

Kegiatan utama yang dilakukan adalah menemukan masalah dalam kegiatan pembelajaran dan kondisi ideal yang diharapkan. Kondisi nyata dalam pembelajaran diketahui melalui observasi, wawancara terhadap dosen pengampu mata kuliah gaido di Program Studi D3 Bahasa Jepang Universitas Teknologi Yogyakarta dan penyebaran angket pada mahasiswa yang sedang mengikuti program internship di hotel Jepang. Sedangkan kondisi ideal yang diharapkan dapat diketahui dengan melakukan analisis capaian pembelajaran. Capaian pembelajaran dalam mata kuliah gaido yaitu: (1) mahasiswa mampu memperkenalkan objek wisata kepada wisatawan asing Jepang; (2) mahasiswa mampu menerapkan etika dasar dalam dunia kerja pemandu wisata dan (3) mahasiswa mampu menguasai bahasa Jepang dalam dunia hospitaliti.

Dosen pengampu menyatakan bahwa kemampuan mahasiswa untuk mengembangkan keterampilan berbicara masih kurang. Berdasarkan hasil observasi saat terjun di lapangan, kemampuan berekspresi masih kurang dan penggunaan kosakata hanya terbatas pada buku pelajaran Minna no 
Nihongo yang bersifat umum. Hasil pengisian angket 10 mahasiswa yang sedang mengikuti program internship menyatakan bahwa, (1) sering terjadi kesalahpahaman saat berkomunikasi dengan pihak hotel disebabkan belum menguasai bahasa Jepang dengan baik; (2) keterbatasan kosakata untuk barang yang digunakan sehari-hari khususnya yang berhubungan dengan dapur, restoran dan front office; (3) sikap, pengetahuan, keterampilan, tata cara dan aturan dalam melayani tamu belum maksimal. Hal ini diperkuat dengan hasil observasi yang menunjukkan bahwa penempatan kerja mahasiswa program internship masih terbatas di bidang pekerjaan house keeping dan dapur, tidak ada yang di bagian restoran atau front office.

Sumber belajar yang digunakan adalah beberapa materi yang berhubungan dengan tempat wisata yang ada di Yogyakarta dari dosen pengampu dan buku Bahasa Jepang untuk Pariwisata oleh T.Chandra (2005) sebagai materi tambahan. Hasil observasi menunjukkan bahwa mahasiswa belum mendapatkan materi khusus percakapan yang membahas bagaimana bahasa yang digunakan saat melayani tamu.

\subsection{Menentukan tujuan pembelajaran (determine instructional goals)}

Hasil angket mahasiswa program internship menunjukkan bahwa kemampuan berkomunikasi masih rendah disebabkan keterbatasan kosakata yang berhubungan dengan dunia hospitality dan tata cara berperilaku terhadap tamu belum maksimal, maka upaya yang dilakukan adalah menyediakan bahan ajar percakapan yang berorientasi pada hospitality dengan setting yang nyata. Hal ini dilakukan agar mahasiswa termotivasi untuk meningkatkan potensi keterampilan berbicara dengan menguasai pemakaian kosakata yang berhubungan dengan hospitality sehingga mampu berkomunikasi dengan baik. Berbicara secara umum dapat diartikan suatu penyampaian maksud (ide, pikiran, gagasan, atau isi hati) seseorang kepada orang lain dengan menggunakan bahasa lisan sehingga maksud tersebut dapat dipahami oleh orang lain. Tarigan dalam Suhartono (2005) mengemukakan berbicara adalah kemampuan mengucapkan bunyibunyi artikulasi atau kata-kata untuk mengekspresikan, menyatakan serta menyampaikan pikiran, gagasan, dan perasaan. 
3.3 Melakukan konfirmasi kepada target sasaran produk (confirm the intended audience)

Berdasarkan hasil pengisian angket kepada mahasiswa program internship, 90\% menyatakan bahwa buku ajar yang selama ini digunakan hanya terbatas kepada hafalan destinasi wisata yang ada di Yogyakarta dan buku bahasa Jepang untuk pariwisata, 90\% dalam buku ajar tesebut tidak diajarkan bagaimana berpenampilan menurut tata cara Jepang yang baik, cara berperilaku terhadap tamu, cara berinteraksi terhadap tamu, pemilihan kata-kata berdasarkan TPO (Time, Place, Occasion) dan kata-kata khusus yang berhubungan dengan benda-benda yang ada di dapur, restoran, dan front office, 95\% mahasiswa menyatakan perlu buku panduan yang berorientasi pada hospitality.

3.4 Mengidentifikasi hal-hal yang dibutuhkan dalam pengembangan (identify required resources)

Buku panduan 国際インターンシップ教本(Buku Ajar Internship untuk Internasional) dapat digunakan sebagai sumber literatur untuk mengembangkan bahan ajar. Karena buku tersebut memuat materi yang dibutuhkan mahasiswa selama mengikuti program internship. Isi buku panduan tersebut membahas mengenai サービス日本語・接遇マ ナー (bahasa Jepang untuk pelayanan・perilaku keramahtamahan).

1.5 Menentukan sistem pengantar yang potensial (determine potential delivery system)

Produk yang dikembangkan untuk mengatasi masalah adalah buku ajar percakapan yang berorientasi pada hospitality. Mahasiswa akan mempelajari cara berpenampilan yang baik, interaksi terhadap tamu, bahasa dalam masyarakat bisnis umum, berbicara di telepon, dan kosakata untuk benda yang digunakan sehari-hari khususnya yang berhubungan dengan dapur, restoran, dan front office. Buku ajar tersebut disajikan dalam bentuk percakapan yang disesuaikan dengan TPO. 
Tabel 2. Hasil Analisis kebutuhan

\begin{tabular}{|c|c|c|}
\hline No. & Tahap & Hasil \\
\hline 1 & $\begin{array}{l}\text { Memvalidasi } \\
\text { kesenjangan } \\
\text { antara kondisi } \\
\text { nyata dengan } \\
\text { kondisi ideal } \\
\text { (validate the } \\
\text { performance } \\
\text { gap) }\end{array}$ & 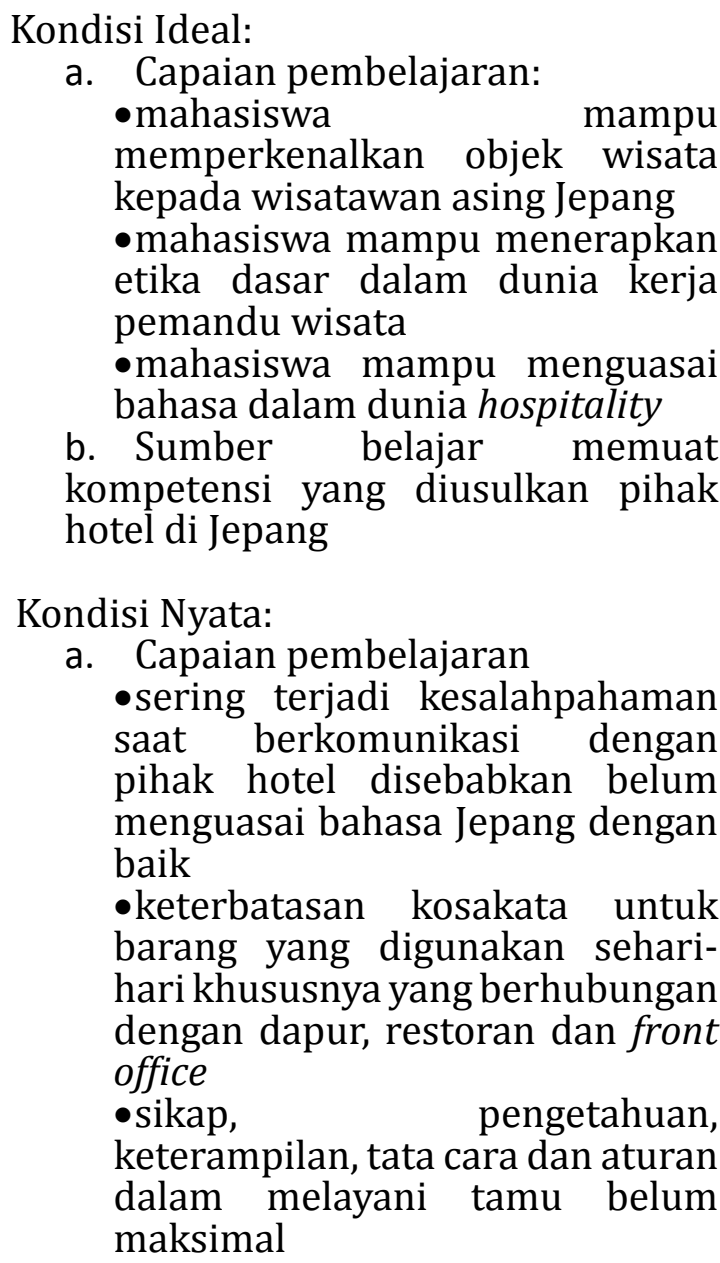 \\
\hline 2 & $\begin{array}{l}\text { Mene ntukan } \\
\text { tujuan pembe- } \\
\text { lajaran (deter- } \\
\text { mineinstruc- } \\
\text { tionalgoals) }\end{array}$ & $\begin{array}{l}\text { Mahasiswa mampu meningkatkan } \\
\text { potensi keterampilan berbicara dengan } \\
\text { menguasai pemakaian kosakata yang } \\
\text { berhubungan dengan hospitaliti } \\
\text { sehingga mampu berkomunikasi dengan } \\
\text { baik }\end{array}$ \\
\hline
\end{tabular}




\begin{tabular}{|c|c|c|}
\hline 3 & $\begin{array}{l}\text { M e l a } \mathrm{k} \mathrm{u} \mathrm{ka} \mathrm{n} \\
\mathrm{k} \text { o } \mathrm{n} \mathrm{f} \text { i } \mathrm{m} \text { a s } \mathrm{i} \\
\text { kepada target } \\
\text { sasaran produk } \\
\text { (confirm the } \\
\text { i } n \text { te } n d \text { ed } \\
\text { audience) }\end{array}$ & $\begin{array}{l}\text { - } 90 \% \text { menyatakan bahwa buku ajar } \\
\text { yang selama ini digunakan hanya } \\
\text { terbatas kepada hafalan destinasi } \\
\text { wisata yang ada di Yogyakarta dan } \\
\text { buku bahasa Jepang untuk pariwisata } \\
\text { - 90\% dalam buku ajar tesebut tidak } \\
\text { diajarkan bagaimana berpenampilan } \\
\text { menurut tata cara Jepang yang baik, } \\
\text { cara berperilaku terhadap tamu, } \\
\text { cara berinteraksi terhadap tamu, } \\
\text { pemilihan kata-kata berdasarkan } \\
\text { TPO (Time, Place, Occasion) dan } \\
\text { kata-kata khusus yang berhubungan } \\
\text { dengan benda-benda yang ada di } \\
\text { dapur, restoran, dan front office } \\
\text { - 95\% mahasiswa menyatakan perlu } \\
\text { buku panduan yang berorientasi } \\
\text { pada hospitality }\end{array}$ \\
\hline 4 & $\begin{array}{l}\text { Mengidenti- } \\
\text { fikasi hal-hal } \\
\text { yang dibu- } \\
\text { tuhkan dalam } \\
\text { pengembangan } \\
\text { (identify re- } \\
\text { quired resourc- } \\
\text { es) }\end{array}$ & $\begin{array}{l}\text { Buku panduan 国際インターンシッ } \\
\text { プ教本(Buku Ajar Internship untuk } \\
\text { Internasional) dapat digunakan } \\
\text { sebagai sumber literatur untuk } \\
\text { mengembangkan bahan ajar. Karena } \\
\text { buku tersebut memuat materi yang } \\
\text { dibutuhkan mahasiswa selama } \\
\text { mengikuti program internship. Isi buku } \\
\text { panduan tersebut membahas mengenai } \\
\text { サービス日本語・接遇マナー (Bahasa } \\
\text { Jepang untuk pelayanan・perilaku } \\
\text { keramahtamahan). }\end{array}$ \\
\hline
\end{tabular}




\begin{tabular}{|c|c|c|}
\hline 5 & $\begin{array}{l}\text { Menentukan } \\
\mathrm{s} \mathrm{i} \mathrm{s} \mathrm{e} \mathrm{m} \\
\mathrm{p} \text { e } \mathrm{g} \text { a n t a r } \\
\text { yang potensial } \\
\text { (determine } \\
\text { potential } \\
d e l i v e r y \\
\text { system) }\end{array}$ & $\begin{array}{l}\text { Buku ajar dikembangkan untuk } \\
\text { meningkatkan keterampilan berbicara } \\
\text { sehingga mampu berkomunikasi }\end{array}$ \\
\hline
\end{tabular}

\section{Simpulan}

Berdasarkan hasil analisis kebutuhan dapat diambil kesimpulan bahwa keterampilan berbicara bahasa Jepang mahasiswa internship Program Studi D3 Bahasa Jepang Universitas Teknologi Yogyakarta di hotel yang ada di Jepang masih kurang. Salah satu upaya untuk mengatasinya adalah dengan menyediakan buku ajar percakapan yang berorientasi pada hospitality, dilengkapi dengan bagaimana berpenampilan yang baik, interaksi terhadap tamu, bahasa dalam masyarakat bisnis umum, berbicara di telepon, dan kosakata untuk benda yang digunakan sehari-hari khususnya yang berhubungan dengan dapur dan restoran. Buku ajar tersebut disajikan dalam bentuk percakapan yang disesuaikan dengan TPO. Tahap analyze pada model pengembangan ADDIE merupakan prosedur yang memberikan petunjuk jelas dan sistematis dalam proses analisis kebutuhan pengembangan buku ajar percakapan berorientasi pada hospitality.

\section{DAFTAR PUSTAKA}

Arakawa, Yoshiko. 2016. So Just What Is Omotenashi? In jStyle magazine. Australia: Nichigo Oress Australia PTY

Branch, R. M. 2009. Instructional Design: The ADDIE Approach.

New York: Springer Science + Bussines Media, LLC

Clark, Herbert H and Eve V. Clark. 1977. Psychology and Language. Harcourt: Brace Jovanovich Publisher 
Dick, Lou Carey, James O'Carey, 2009, The Systematic Design Of Instruction, $7^{\text {th }}$ Editions, Pearson Education Ltd., London

E.Pendit. Nyoman. 2007. Ilmu Pariwisata. Jakarta : Pradnya Paramita

Hershberger, M. 1999. A Christian View of Hospitality: Expecting Surprises. Herald Press

Komalasari, K. 2010. Pembelajaran Kontekstual: Konsep dan Aplikasi. Bandung: Refika Aditama

Lestari Ika. 2013. Pengembangan Bahan Ajar Berbasis Kompetensi Sesuai dengan Kurikulum Tingkat Satuan Pendidikan. Padang: Akadenia Permata

Mudlofir Ali. 2012. Aplikasi Pengembangan Kurikulum Tingkat Satuan Pendidikan dan Bahan Ajar dalam Pendidikan Agama Islam. Jakarta: Rajawali Pers

Majid Abdul. 2008. Perencanaan Pembelajaran. Bandung: Remaja Rosdakarya

Nakano, Lloyd S. 2008. Hospitality - Omotenashi Comparing Apples to Oranges.. In Japan Spotlight Magazine. Japan

Sugiarto. 2011. Landasan Pengembangan Bahan Ajar. Materi Workshop Penyusunan Buku Ajar Bagi Dosen Politeknik Kesehatan Kemenkes Semarang

Sujatno, A, Bambang. Hospitality Secret Skills, Attitudes, and Performances for Restaurant Manager. Yogyakarta: ANDI

Tarigan, Djago, dkk. 1997. Pengembangan Keterampilan Berbicara. Jakata: Departemen Pendidikan dan Kebudayaan

Genshitsu Sen, Soshitsu Sen. 2004. Urasenke Chado Textbook. Kyoto. Urasenke Foundation

http://www.indonesiacultureandtourism.com/2015/11/format-penulisanmakalah-untuk-ujian.html diakses 16 Februari 2018 